DOI

\author{
А.Є. ГОРБАНЬ
}

\title{
МОНІТОРИНГ ЗАСОБІВ ІННОВАЦІЙНОГО ЗАБЕЗПЕЧЕННЯ У СФЕРІ ОХОРОНИ ЗДОРОВ'Я УКРАЇНИ 3 ПРОБЛЕМИ ЗАХВОРЮВАНОСТІ НА НАЙБІЛЬШ СОЦІАЛЬНО НЕБЕЗПЕЧНІ ТА СОЦІАЛЬНО ЗНАЧУЩІ ХВОРОБИ ЗА 2011-2014 РОКИ
}

\author{
1Український центр наукової медичної інформації та патентно-ліцензійної роботи МОЗ України, м. Київ \\ 2ДУ «Український інститут стратегічних досліджень МОЗ України», м. Київ \\ ${ }^{3} Д В Н 3$ «Тернопільський державний медичний університет ім. І.Я. Горбачевського МОЗ України»
}

\begin{abstract}
Мета: моніторинг інноваційного забезпечення у сфері охорони здоров'я України з проблеми захворюваності на найбільш соціально небезпечні та соціально значущі хвороби за 2011-2014 роки.

Матеріали і методи. Проведено ретроспективний аналіз 378 нововведень, 167 інформаційних листів, 130 методичних рекомендацій; використано методи експертної оцінки, статистичного, системного, структурно-логічного та кластерного аналізу.

Результати. За період 2011-2014 рр. найбільшу кількість інновацій запропоновано за напрямками «Онкологія» та «Хвороби системи кровообігу». Визначено недостатнє інноваційне забезпечення практичної охорони здоров'я з актуальних питань діагностики, профілактики, лікування та реабілітації хворих у результаті травм, отруєнь та наслідків дії зовнішніх чинників.

Висновки. Для покращання якості медичної допомоги в лікувально-профрілактичних закладах, підвищення рівня здоров'я населення науковим установам необхідно більше уваги приділяти розробкам з питань діагностики, профрілактики, лікування та реабілітації хворих у результаті травм, отруєнь та наслідків дії зовнішніх чинників.
\end{abstract}

КЛЮчОВІ СЛОВА: інноваційне забезпечення, нововведення, інформаційні листи, методичні рекомендації, захворюваність.

Однією із найважливіших проблем, які на сучасному етапі розвитку українського суспільства потребують невідкладного вирішення, $€$ захворюваність на найбільш соціально небезпечні та соціально значущі хвороби. Зростання захворюваності на найбільш соціально небезпечні та соціально значущі хвороби є загрозливим у контексті процесів відтворення як населення загалом, так і трудових ресурсів, що в подальшому загострить негативні тенденції у динаміці демографрічних процесів і наслідки, що з ними пов'язані (зменшення чисельності працездатного населення, збільшення навантаження на систему охорони здоров'я та пенсійного забезпечення, втрата інтелектуального потенціалу тощо) [2].

За даними Д3 «Центр медичної статистики МО3 України», до найбільш соціально небезпечних та соціально значущих захворювань належать хвороби системи кровообігу, новоутворення, травми, отруєння та наслідки дії зовнішніх чинників, цукровий діабет, туберкульоз, ВІЛ-інфекція та СНІД [3]. Ці хвороби мають негативні соціально-економічні наслідки для суспільства.

Серед причин смертності населення України за період 2011-2013 рр. на першому місці знаходилися хвороби системи кровообігу. У 2013 р. питома вага хвороб системи кровообігу у структурі смерт- ності становила 66,5\%. Друге та третє рангові місця серед причин смертності займали новоутворення та зовнішні причини смерті відповідно. У 2013 р. питома вага новоутворень у структурі смертності становила $13,9 \%$, питома вага зовнішніх причин смерті - 6,1\% [1;3].

Важливою проблемою сьогодення залишається захворюваність на цукровий діабет (ЦД). За останні двадцять років кількість вперше зареєстрованих випадків ЦД збільшилася на 57,5\% (у 1993 р. захворюваність на ЦД склала 115,6, а в 2013 р. - 272,0 на 100 тис. нас.). Поширеність ЦД з 2011 р. до 2013 р. значно зросла - на 8,83\%, що вказує на необхідність більшої уваги до розроблення нових технологій профілактики та лікування ЦД та впровадження їх у практику закладів охорони здоров'я [1].

Досить високими залишаються в Україні показники захворюваності на туберкульоз - 67,9 на 100 тис. нас. (2013 р.). Для порівняння: у Центральній Європі переважає середній рівень захворюваності (10-30 на 100 тис. нас.), а у Західній Європі - низький (до 10 на 100 тис. нас.).

В Україні залишається напруженою епідемічна ситуація з ВІЛ-інфрекції-продовжується поширення ВІЛ серед населення, зростає кількість ВІЛ-інфікованих осіб і хворих на СНІД. У 2013 р. було зареєстровано 21631 новий випадок ВІЛ-інфекції (захворюваність

( А.Є. Горбань, Л.І. Закрутько, О.М. Дзюба, Л.Г. Білан, О.О.Шевчук, 2015 
на ВІЛ-інфекцію становила 47,6 на 100 тис. нас.), у тому числі 9362 випадки СНІДу (захворюваність на СНІД становила 20,6 на 100 тис. нас.) [1;3].

Впровадження нових технологій та обладнання для якісного медичного обслуговування в лікувально-профрілактичні заклади допоможе вирішити проблему вдосконалення діагностики, профрілактики та лікування найбільш соціально небезпечних та соціально значущих хвороб, організації своєчасної медичної допомоги населенню.

Мета дослідження - провести моніторинг інноваційного забезпечення у сфрері охорони здоров'я України з проблеми захворюваності на найбільш соціально небезпечні та соціально значущі хвороби за 2011-2014 роки.

Матеріали і методи. Експертами Українського центру наукової медичної інформації та патентноліцензійної роботи МО3 України проаналізовано основні засоби інноваційного забезпечення у сорері охорони здоров'я України з проблеми захворюваності на найбільш соціально небезпечні та соціально значущі хвороби за 2011-2014 рр.: інформаційні листи (ІЛ), методичні рекомендації
(MP), погоджені МОЗ України, Реєстри галузевих нововведень за 2011-2013 рр., Перелік наукової (науково-технічної) продукції, призначеної для впровадження досягнень медичної науки у сферу охорони здоров'я за 2014 р.

Застосовано методи експертної оцінки, статистичного, системного та структурно-логічного аналізу.

Результати дослідження та їх обговорення. Ретроспективний аналіз засобів наукової комунікації з проблеми найбільш соціально небезпечних та соціально значущих хвороб у сфері охорони здоров'я України показав, що за період 20112014 рр. було надруковано 167 ІЛ та погоджено в МО3 України 130 МР.

Вивчення динаміки видання ІЛ вказує на тенденцію до збільшення кількості ІЛ, присвячених проблемам найбільш соціально небезпечних та соціально значущих хвороб, протягом 2011-2013 рр. У 2013 р. запропоновано наукових розробок, висвітлених в ІЛ, на 37,3\% більше, ніж у 2011 р. У 2014 р. спостерігалося зменшення кількості ІЛ, присвячених вказаним захворюванням, на 25,5\% порівняно з 2013 р. (табл. 1).

Таблиця 1. Кількість інформаційних листів з проблеми найбільш соціально небезпечних та соціально значущих хвороб за період 2011-2014 рр.

\begin{tabular}{|c|c|c|c|c|c|}
\hline \multirow{2}{*}{$\begin{array}{c}\text { Найменування класів хвороб } \\
\text { та окремих нозологій }\end{array}$} & \multicolumn{5}{|c|}{ Кількість інфрормаційних листів } \\
\hline & усього & 2011 p. & 2012 p. & 2013 p. & 2014 p. \\
\hline Хвороби системи кровообігу & 57 & 10 & 23 & 17 & 7 \\
\hline $\begin{array}{l}\text { Травми, отруєння та деякі інші } \\
\text { наслідки дії зовнішніх чинників }\end{array}$ & 15 & 2 & 5 & 2 & 6 \\
\hline Новоутворення & 60 & 17 & 6 & 22 & 15 \\
\hline Цукровий діабет & 11 & 1 & 6 & 1 & 3 \\
\hline Туберкульоз & 14 & - & 4 & 5 & 5 \\
\hline ВІЛ/СНІД & 10 & 2 & 2 & 4 & 2 \\
\hline Усього & 167 & 32 & 46 & 51 & 38 \\
\hline
\end{tabular}

Установи-розробники найбільшу увагу приділяли проблемам онкології та хвороб системи кровообігу (надруковано 60 та 57 ІЛ відповідно), тоді як інновації з актуальних питань діагностики, профілактики, лікування та реабілітації хворих у результаті травм, отруєнь та наслідків дії зовнішніх чинників представлені значно меншою кількістю розробок - 15 ІЛ.

Результати проведеного дослідження вказують на тенденцію до зменшення кількості МР, погоджених МОЗ України, за період 2011-2013 рр. У 2013 р. було погоджено в МО3 України 22 MP, що майже вдвічі менше, ніж у 2011 р. - 42 МР. У 2014 р. підвищилася активність наукових установ щодо розробки MP: у MO3 України було погоджено 36 MP 3 проблеми найбільш соціально небезпечних та соціально значущих хвороб, що на 63,6\% більше, ніж у 2013 р. (табл. 2).

У 2014 р. в МОЗ України було погоджено МР на 14,3\% менше порівняно з 2011 р., у яких були представлені нові наукові розробки з проблем най- більш соціально небезпечних та соціально значущих хвороб.

Найбільша кількість МР за період 2011-2014 рр. була присвячена інноваціям за напрямком «Онкологія» - 58 МР, тоді як таким соціально небезпечним та соціально значущим хворобам, як ВІЛінфекція/СНІД, туберкульоз, приділялася недостатня увага (7 та 6 МР відповідно).

Одним із важливих засобів наукової комунікації $€$ Реєстр галузевих нововведень (далі - Реєстр), який щорічно формувався у 2011-2013 рр. за результатами науково-дослідних робіт, виконаних в установах МО3 України. 32014 р. усі повідомлення про нові наукові розробки, які можуть бути використані в закладах практичної охорони здоров'я, увійшли до Переліку наукової (науково-технічної) продукції, призначеної для впровадження досягнень медичної науки у сореру охорони здоров'я (далі - Перелік), відповідно до спільного наказу МОЗ та НАМН України від 13.11.2013 р. № 969/97 
Таблиця 2. Кількість методичних рекомендацій з проблеми найбільш соціально небезпечних та соціально значущих хвороб за період 2011-2014 рр.

\begin{tabular}{|l|c|c|c|c|c|}
\hline \multirow{2}{*}{$\begin{array}{c}\text { Найменування класів хвороб та } \\
\text { окремих нозологій }\end{array}$} & \multicolumn{5}{|c|}{ Кількість методичних рекомендацій } \\
\cline { 2 - 6 } & усього & $2011 \mathrm{p}$. & $2012 \mathrm{p}$. & $2013 \mathrm{p.}$ & $2014 \mathrm{p.}$ \\
\hline Хвороби системи кровообігу & 34 & 9 & 11 & 4 & 10 \\
\hline $\begin{array}{l}\text { Травми, отруєння та деякі інші } \\
\text { наслідки дії зовнішніх чинників }\end{array}$ & 14 & 7 & 3 & 3 & 1 \\
\hline Новоутворення & 58 & 19 & 12 & 10 & 17 \\
\hline Цукровий діабет & 11 & 5 & 1 & 2 & 3 \\
\hline Туберкульоз & 6 & 2 & 0 & 1 & 3 \\
\hline ВІЛ/СНІД & 7 & 0 & 3 & 2 & 2 \\
\hline Усього & $\mathbf{1 3 0}$ & $\mathbf{4 2}$ & $\mathbf{3 0}$ & $\mathbf{2 2}$ & $\mathbf{3 6}$ \\
\hline
\end{tabular}

«Про удосконалення впровадження досягнень медичної науки у ссреру охорони здоров'я», зареєстрованого в Міністерстві юстиції України 05.12.2013 р. 3a № 2068/24600.

За період 2011-2014 рр. до Реєстру та Переліку увійшли 378 наукових повідомлень про нові розробки 3 проблеми найбільш соціально небезпечних та соціально значущих хвороб [4-9]. Найбільша кількість наукових повідомлень за вказаний період була присвячена питанням діагностики, профрілактики та лікування хвороб системи кровообігу - 150 пропозицій нових наукових розробок.

Ретроспективний аналіз наукових повідомлень, які ввійшли до Реєстрів 2011-2013 рр. та Переліку 2014 р., показав, що найбільш продуктивним щодо нових розробок з даної проблеми був 2014 р. кількість повідомлень у цьому році була утричі більшою порівняно з 2011 р. (табл. 3).

Таблиця 3. Кількість наукових повідомлень про нові розробки з проблеми найбільш соціально небезпечних та соціально значущих хвороб за період 2011-2014 pр.

\begin{tabular}{|l|c|c|c|c|c|}
\hline \multirow{2}{*}{$\begin{array}{c}\text { Найменування класів хвороб та } \\
\text { окремих нозологій }\end{array}$} & \multicolumn{5}{|c|}{ Кількість наукових повідомлень } \\
\cline { 2 - 6 } & усього & 2011 р. & 2012 р. & 2013 р. & 2014 р. \\
\hline Хвороби системи кровообігу & 150 & 37 & 34 & 27 & 52 \\
\hline $\begin{array}{l}\text { Травми, отруєння та деякі інші } \\
\text { наслідки дії зовнішніх чинників }\end{array}$ & 49 & 7 & 14 & 13 & 15 \\
\hline Новоутворення & 115 & 4 & 22 & 22 & 67 \\
\hline Цукровий діабет & 34 & 1 & 6 & 8 & 19 \\
\hline Туберкульоз & 19 & 1 & 4 & 6 & 8 \\
\hline ВІЛ/СНІД & 11 & - & 6 & 3 & 2 \\
\hline Всього & $\mathbf{3 7 8}$ & $\mathbf{5 0}$ & $\mathbf{8 6}$ & $\mathbf{7 9}$ & $\mathbf{1 6 3}$ \\
\hline
\end{tabular}

Слід зазначити про значне збільшення нових наукових розробок за напрямком «Онкологія» за період 2011-2014 рр. У 2014 р. у цій сорері запропоновано у 16,8 разу більше інновацій порівняно 3 2011 роком.

За період 2011-2014 рр. спостерігалося значне зростання пропозицій щодо нових розробок з приводу діагностики, профрілактики та лікування ЦД. У 2014 р. запропоновано 19 інноваційних пропозицій, що у 2,4 разу більше, ніж у 2013 р., та у 19 разів більше, ніж у 2011 р. (табл. 3).

Встановлено тенденцію до збільшення протягом 2011-2014 рр. кількості повідомлень про інновації з проблеми туберкульозу. Якщо у 2011 р. запропонована всього одна нова розробка, то у 2014 р. таких розробок було вісім.

Проведене дослідження показало, що протягом 2011-2014 рр. науковцями представлено до розгляду досить мало повідомлень, присвячених питанням діагностики, профрілактики, лікування та реабілітації хворих у результаті травм, отруєнь та наслідків дії зовнішніх чинників. До Реєстрів та Переліку ввійшло 49 інновацій із вказаної проблеми, що у 2,3 та у 3,1 разу менше, ніж з проблем онкології та хвороб системи кровообігу відповідно.

Досить мало за розглянутий період надійшло від наукових установ-розробників інноваційних пропозицій з актуальної проблеми ВІЛ-інфекції та СНІДу. Так, у 2011 р. не було жодної пропозиції, у 2012 р. - шість пропозицій, що становить найбільшу кількість порівняно 3 іншими досліджуваними роками. Далі спостерігається тенденція до зменшення кількості нових розробок, присвячених питанням діагностики, профілактики та лікування хворих з ВІЛ-інфекцією та СНІДом.

\section{Висновки}

Моніторинг основних засобів наукової комунікації у сорері охорони здоров'я України з проблеми 
захворюваності на найбільш соціально небезпечні та соціально значущі хвороби за 2011-2014 рр. показав, що найбільше інновацій запропоновано за напрямками «Онкологія» та «Хвороби системи кровообігу».

Результати проведеного дослідження вказують на значне зростання пропозицій щодо нових розробок з приводу діагностики, профрілактики та лікування цукрового діабету, які ввійшли до Реєстрів галузевих нововведень 2011-2013 рр. та Переліку наукової (науково-технічної) продукції, призначеної для впровадження досягнень медичної науки у сореру охорони здоров'я, 2014 року.

Встановлено недостатнє інноваційне забезпечення практичної охорони здоров'я з актуальних питань діагностики, профрілактики, лікування та реабілітації хворих в результаті травм, отруєнь та наслідків дії зовнішніх чинників. Науковим установам необхідно більше уваги приділяти вказаній проблемі для покращання якості медичної допомоги в лікувально-профрілактичних закладах, підвищення рівня здоров'я населення.

Перспективи подальших досліджень полягають у пошуку шляхів вирішення питання недостатньої ефективності системи інноваційного забезпечення в практичній охороні здоров'я 3 проблеми захворюваності на найбільш соціально небезпечні та соціально значущі хвороби. Реформа системи медичного обслуговування, яка проводиться сьогодні, неможлива без повноцінної, своєчасної та якісної наукової інфрормації, спрямованої на розробку та впровадження в практику нових технологій.

\section{Список літератури}

1. Державна служба статистики України [Електронний ресурс]. - Режим доступу: http://www.ukrstat.gov.ua.

2. Зибарева О. В. Поширення соціальних хвороб як наслідок акультурації українського суспільства [Електронний ресурс] / О. В. Зибарева // Ефрективна економіка. - 2013. - № 9. - Режим доступу : http://www.economy.nayka. com.ua.

3. Основні показники здоров'я населення та діяльності системи охорони здоров'я України. - Київ : МОЗ України, ДЗ «Центр медичної статистики МОЗ України», 2014.

4. Перелік наукової (науково-технічної) продукції, призначеної для впровадження досягнень медичної науки у сореру охорони здоров'я. Випуск 1. - Київ, 2014. - 280 с.

5. Реєстр галузевих нововведень. Випуск 34-35. - Київ, 2011. - 280 с.

6. Реєстр галузевих нововведень. Випуск 36. - Київ, 2012. - 236 с.

7. Реєстр галузевих нововведень. Випуск 37. - Київ, 2012. - 228 с.

8. Реєстр галузевих нововведень. Випуск 38-39. Частина І. - Київ, 2013. - 194 с.

9. Реєстр галузевих нововведень. Випуск 38-39. Частина II. - Київ, 2013. - 214 с.

\section{МОНИТОРИНГ СРЕДСТВ ИННОВАЦИОННОГО ОБЕСПЕЧЕНИЯ В СФЕРЕ ЗДРАВООХРАНЕНИЯ УКРАИНЫ ПО ПРОБЛЕМЕ ЗАБОЛЕВАЕМОСТИ НАИБОЛЕЕ СОЦИАЛЬНО ОПАСНЫМИ И СОЦИ- АЛЬНО ЗНАЧИМЫМИ БОЛЕЗНЯМИ ЗА 2011-2014 ГОДЫ \\ А.Е. Горбань ${ }^{1}$, Л.И. Закрутько1, А.Н. Дзюба², Л.Г. Белан ${ }^{1}$, О.О. Шевчук \\ 1 Украинский центр научной медицинской информации и патентно-лицензионной работы, г. Киев \\ 2 ГУ «Украинский институт стратегических исследований МЗ Украины», г. Киев \\ ${ }^{3}$ ГВУЗ «Тернопольский государственный медицинский университет им. И.Я. Горбачевского МЗ Украины»}

Цель: мониторинг средств инновационного обеспечения в сфере здравоохранения Украины по проблеме заболеваемости наиболее социально опасными и социально значимыми болезнями за 2011-2014 годы.

Материалы и методы. Проведен ретроспективный анализ 378 нововведений, 167 инорормационных писем, 130 методических рекомендацій; применялись методы экспертной оценки, статистического, системного, структурно-логического и кластерного анализа.

Результаты. За период 2011-2014 гг. наибольшее количество инноваций предложено по направлениям «Онкология» и «Болезни системы кровообращения». Определено недостаточное инновационное обеспечение практического здравоохранения по актуальным вопросам диагностики, просрилактики, лечения и реабилитации больных в результате травм, отравлений и последствий воздействия внешних причин.

Выводы. Для улучшения качества медицинской помощи в лечебно-профилактических учреждениях, повышения уровня здоровья населения научным учреждениям необходимо больше внимания уделять разработкам, посвященным вопросам диагностики, профилактики, лечения и реабилитации больных после травм, отравлений и последствий воздействия внешних причин.

КЛЮЧЕВЫЕ СЛОВА: инновационное обеспечение, нововведения, информационные письма, методические рекомендации, заболеваемость. 


\section{MONITORING OF FACILITIES OF THE INNOVATIVE PROVIDING IN THE FIELD OF MORBIDITY ON MOST SOCIALLY DANGEROUS AND SOCIALLY MEANINGFUL DISEASES IN UKRAINE HEALTH CARE FOR 2011-2014}

A.E. Gorban' ${ }^{1}$ L.I. Zakrutko' , A.N. Dzyuba², L.G. Bilan ${ }^{1}$, O.O. Shevchuk ${ }^{3}$

${ }^{1}$ Ukrainian center of scientific medical information and patent-licensed work, Kyiv

2 PE“Ukrainian Institute of Strategic Researches MHC of Ukraine", Kyiv

${ }^{3}$ SHEI «Ternopil State Medical University by I. Ya. Horbachevsky Ministry of Health of Ukraine»

Purpose: monitoring of the innovative providing in the field of morbidity on most socially dangerous and socially meaningful diseases in Ukraine health care for 2011-2014.

Materials and methods. There was performed a retrospective analysis for 378 innovations, 167 informative letters, 130 methodical recommendations. During work the method of expert evaluations, the statistical methods, the method of system analysis, the method of structural and logical analysis were used.

Results. Research showed that the greatest number innovations on directions «Oncology» and «Blood circulatory diseases» are presented for period 2011-2014. The insufficient innovative providing of practical health protection on pressing questions of diagnostics, prophylaxis, treatment and rehabilitation of patients as a result of traumas, poisoning and consequences of action of external factors are defined.

Conclusions. For the improvement of quality of health care in medical and preventive establishments, increase of population health level to scientific establishments it is necessary to spare more attention to developments on questions diagnostics, prophylaxis, treatment and rehabilitation of patients as a result of traumas, poisoning and consequences of the action of external factors.

KEY WORDS: innovative providing, innovations, informative letters, methodical recommendations, morbidity.

Відомості про авторів:

Рукопис надійшов до редакції 15.11.2015 p.

Горбань Андрій Євгенович - к.мед.наук, директор Українського центру наукової медичної інформації та патентно-ліцензійної роботи МОЗ України; тел.: + 38(044) 428-37-22;

Закрутько Леся Іллівна - к.мед.н., доц., заступник директора з наукової роботи Українського центру наукової медичної інфрормації та патентно-ліцензійної роботи МОЗ України; тел.: + 38(044) 428-37-22; e-mail:

Дзюба Олександр Миколайович - д.мед.н., проф., заступник директора з наукової роботи ДУ «Український інститут стратегічних досліджень МО3 України»; тел.: + 38(044) 576-41-49.

Білан Лариса Григорівна - к.мед.н., завідувач відділу дослідження та розвитку електронних інформаційних технологій в сфері охорони здоров'я України Українського центру наукової медичної інсормації та патентноліцензійної роботи МОЗ України; тел.: + 38(044) 428-37-22;

Шевчук Оксана Олегівна - кандидат медичних наук, керівник наукового відділу, доцент кафедри фрармакології 3 клінічною фрармакологією Тернопільського державного медичного університету імені І.Я. Горбачевського тел.: + 38 (0352) 52-39-87. 